\title{
Nova gestão
}

\section{New management}

É com muita honra, e também cientes da responsabilidade que nos aguarda, que assumimos a Editoria Científica dos Anais Brasileiros de Dermatologia. Afinal, nossa revista foi fundada em 1925 e, desde então, ilustres colegas nos antecederam como editores, sempre atuando com brilhantismo e intensa dedicação.

$\mathrm{Na}$ gestão que ora se inicia, contamos com a participação dos competentes doutores Renan Bonamigo e Vítor Reis, na qualidade de Editores Associados, além do apoio da dedicada equipe dos Anais, formada por Vanessa Zampier, Nazareno de Souza e Samuel Peixoto. Juntos, trabalharemos para que os Anais Brasileiros de Dermatologia continuem sendo motivo de orgulho para os associados.

Os Anais Brasileiros de Dermatologia, no momento, estão indexados em várias bases, tais como o SciELO, Scopus, Embase, Latindex, LILACS, Periódica, TDB, Web of Science.Tudo isso representa uma validação a mais, uma espécie de selo de garantia que nos permite depositar com maior segurança os nossos trabalhos. Ressaltamos que nossa finalidade é que este periódico seja um cabedal importante de informações científicas.

Para facilitar o envio de trabalhos, no início deste ano, contaremos com o sistema de submissão online, o que conferirá mais objetividade e rapidez. Desse modo, os trabalhos poderão ser enviados e acompanhados pelos autores com maior agilidade e clareza.

No sentido de aumentar a visibilidade dos nossos trabalhos e também de permitir permutas com outras revistas, passaremos, ainda, a ter disponibilizados na língua inglesa - a língua da ciência - todos os artigos, na íntegra, no site dos Anais Brasileiros de Dermatologia (www.anaisdedermatologia.org.br). Nada obstante, a forma impressa, em português, continuará sendo enviada a todos os sócios, bem como a diversos serviços de dermatologia e bibliotecas no exterior.

Neste número, publicamos, com muita emoção, um caso clínico do saudoso professor Sampaio, que, em Fortaleza, durante o último congresso da Sociedade Brasileira de Dermatologia, manifestou seu interesse em colaborar com os Anais Brasileiros de Dermatologia por meio da publicação do referido caso. No início do mês de outubro, já muito enfraquecido, o brilhante mestre nos recebeu em sua casa e renovou tal intenção, ato que veio a repetir mesmo em seus últimos dias, internado em fase final, por meio de sua assistente, Dr $^{\text {a }}$ Christiane D. Piazza.

A recém-criada seção de Dermatopatologia é apresentada aos associados como mais um espaço científico, com o intuito de incrementar e enriquecer a nossa formação especializada.

Por último, convidamos a todos, com muito entusiasmo, a publicarem em nossa revista, pois, dessa maneira, melhoraremos a sua qualidade. Também é muito importante lembrar aos colegas que, quando mandarem os seus preciosos artigos, não se esqueçam de citar os Anais Brasileiros de Dermatologia nas referências bibliográficas; assim, aumentaremos o fator de impacto e contribuiremos, uma vez mais, para a elevação de nosso periódico ao topo das publicações científicas mundiais. Já estamos chegando lá.

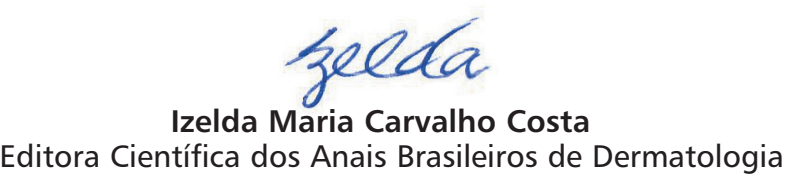

Como citar este artigo/How to cite this article: Costa IMC. Nova gestão. An Bras Dermatol. 2009;84(1):7. 